\title{
J \\ Dihydrophenanthridine: A New and Easily Regenerable NAD(P)H Model for Biomimetic Asymmetric Hydrogenation
}

\author{
Qing-An Chen, ${ }^{\dagger}$ Kai Gao, ${ }^{\dagger}$ Ying Duan, ${ }^{\dagger}$ Zhi-Shi Ye, ${ }^{\dagger}$ Lei Shi, ${ }^{\dagger}$ Yan Yang, ${ }^{\dagger}$ and Yong-Gui Zhou*, ${ }^{\dagger}, \neq$ \\ ${ }^{\dagger}$ State Key Laboratory of Catalysis, Dalian Institute of Chemical Physics, Chinese Academy of Sciences, Dalian 116023, China \\ ${ }^{\ddagger}$ State Key Laboratory of Organometallic Chemistry, Shanghai Institute of Organic Chemistry, Chinese Academy of Sciences, \\ Shanghai 200032, China
}

\section{Supporting Information}

ABSTRACT: A new and easily regenerable $\mathrm{NAD}(\mathrm{P}) \mathrm{H}$ model 9,10dihydrophenanthridine (DHPD) has been designed for biomimetic asymmetric hydrogenation of imines and aromatic compounds. This reaction features the use of hydrogen gas as terminal reductant for the regeneration of the DHPD under the mild condition. Therefore, the substrate scope is not limited in benzoxazinones; the biomimetic asymmetric hydrogenation of benzoxazines, quinoxalines, and quinolines also gives excellent activities and enantioselectivities. Meanwhile, an

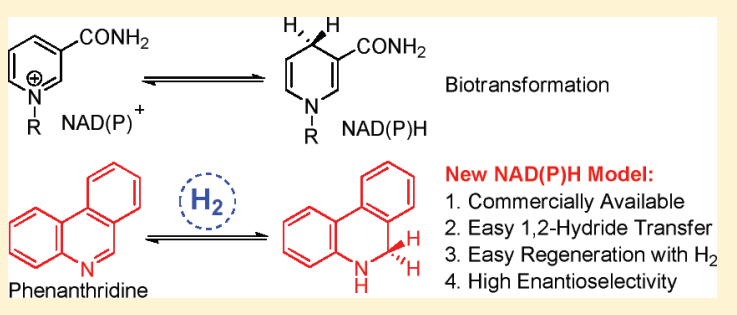
unexpected reversal of enantioselectivity was observed between the reactions promoted by the different $\mathrm{NAD}(\mathrm{P}) \mathrm{H}$ models, which is ascribed to the different hydride transfer pathway.

\section{INTRODUCTION}

As a couple of the most important coenzymes found in living cells, reduced nicotinamide adenine dinucleotide (NADH) and nicotinamide adenine dinucleotide phosphate $(\mathrm{NADPH})$ play great roles in reduction-oxidation (redox) metabolism. ${ }^{1}$ Therefore, $\mathrm{NAD}(\mathrm{P}) \mathrm{H}$ mimics have become one of the most significant fields in biomimetic chemistry over the past few decades (Figure 1). Despite that much progress has been

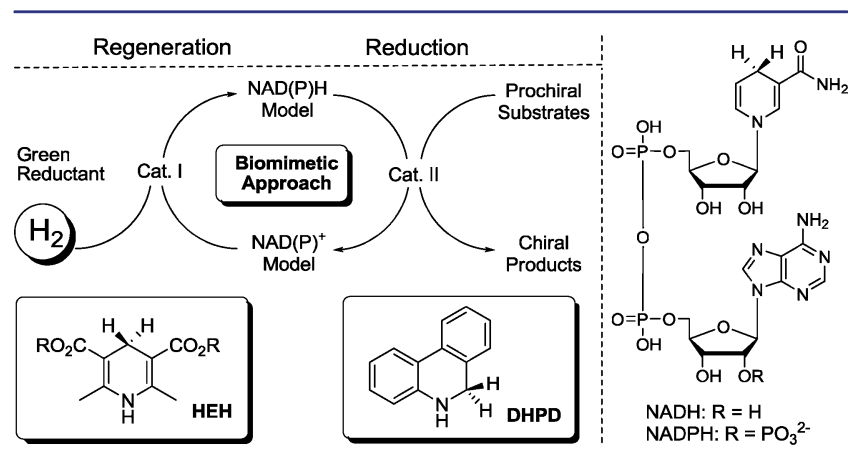

Figure 1. (A) $\mathrm{NAD}(\mathrm{P}) \mathrm{H}$ models-mediated biomimetic reduction (Cat. I, regeneration catalyst; Cat. II, reduction catalyst; HEH, Hantzsch esters; DHPD, 9,10-dihydrophenanthridine).

achieved, most of the current research focuses on the hydride transfer ability and selectivity in redox reactions rather than the renewable capability of $\mathrm{NAD}(\mathrm{P}) \mathrm{H}$ models. ${ }^{2}$

As one of the simplest $\mathrm{NAD}(\mathrm{P}) \mathrm{H}$ models, Hantzsch esters $(\mathrm{HEH})^{3}$ have been widely and successfully used as reductant in the enantioselective transfer hydrogenation of unsaturated bonds $\left(\mathrm{C}=\mathrm{C}, \mathrm{C}=\mathrm{N}\right.$, and $\mathrm{C}=\mathrm{O}$ ) using organocatalysts ${ }^{4,5}$ and metal catalysts (Figure 1). ${ }^{6}$ Recently, we reported an efficient method for in situ regeneration of $\mathrm{HEH}$ from Hantzsch pyridine under hydrogen gas in biomimetic asymmetric hydrogenation (Scheme 1 ). ${ }^{7 \mathrm{a}}$ Although excellent

Scheme 1. Biomimetic Asymmetric Hydrogenation of Benzoxazinones Using Catalytic Amount of Hantzsch Esters

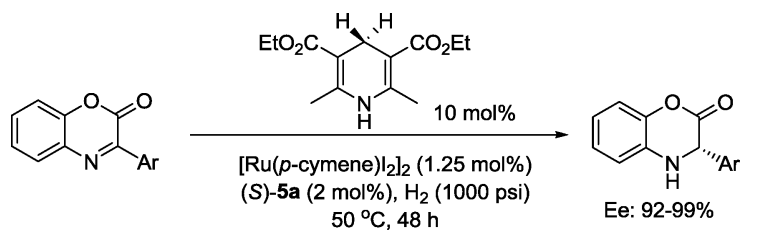

enantioselectivities were obtained, the regeneration condition of $\mathrm{HEH}$ was harsh, and the substrate scope was limited to benzoxazinones which underwent no background reaction. Developing a milder biomimetic asymmetric hydrogenation is of great interest in the field of $\mathrm{NAD}(\mathrm{P}) \mathrm{H}$ mimics and good for extending the substrate generality. Based on our previous work on asymmetric hydrogenation, ${ }^{8}$ we envisioned that looking for a new and easily regenerable $\mathrm{NAD}(\mathrm{P}) \mathrm{H}$ model is probably a good choice.

To the best of our knowledge, the dihydropyridine amido group is the key structure in $\mathrm{NAD}(\mathrm{P}) \mathrm{H}$ models and plays an important part in the hydride transfer process. Therefore, most of the currently successful $\mathrm{NAD}(\mathrm{P}) \mathrm{H}$ models, such as $\mathrm{HEH}^{3}$ and 1-benzyl-1,4-dihydronicotinamide (BNAH), ${ }^{9}$ contain a dihydropyridine skeleton. Based on the design of $\mathrm{NAD}(\mathrm{P}) \mathrm{H}$ models, the search of $\mathrm{NAD}(\mathrm{P}) \mathrm{H}$ models that can be used in the

Received: December 15, 2011

Published: January 3, 2012 
biomimetic asymmetric hydrogenation process takes into account four requirements: (a) easy preparation of the $\mathrm{NAD}(\mathrm{P}) \mathrm{H}$ model from commercially available materials; (b) easy hydride transfer from the $\mathrm{NAD}(\mathrm{P}) \mathrm{H}$ model to the prochiral substrate; (c) easy regeneration of the $\mathrm{NAD}(\mathrm{P}) \mathrm{H}$ model from the oxidized form under hydrogen gas; (d) easy control of the reaction enantioselectivity. Herein, we developed a new and easily regenerable $\mathrm{NAD}(\mathrm{P}) \mathrm{H}$ model 9,10dihydrophenanthridine (DHPD) for biomimetic asymmetric hydrogenation of imines and aromatic compounds (Scheme 2).

Scheme 2. Biomimetic Asymmetric Hydrogenation Promoted by Dihydrophenanthridine

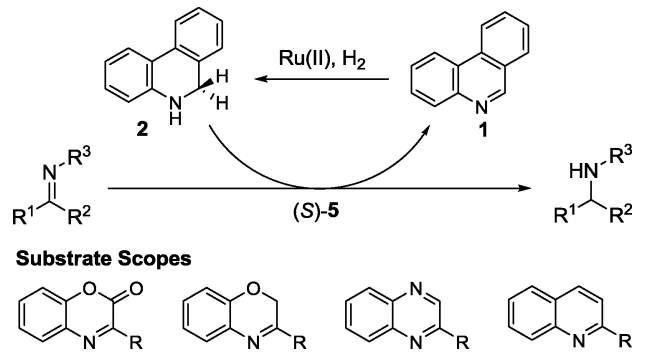

Owing to the fact that only mild condition was required for regeneration of DHPD, the substrate scope is not just limited in benzoxazinones; the biomimetic asymmetric hydrogenation of benzoxazines, quinoxalines, and quinolines also gives excellent activities and enantioselectivities.

\section{RESULTS AND DISCUSSION}

Regeneration of NAD(P)H Model-DHPD from Phenanthridine. Its easy preparation and dehydroaromatization make 9,10-dihydrophenanthridine (DHPD) a promising candidate to act as a new and renewable $\mathrm{NAD}(\mathrm{P}) \mathrm{H}$ model in biomimetic asymmetric hydrogenation systems. The 1,2-hydride transfer pathway occurring in DHPD-mediated reduction is different from the common 1,4-hydride transfer of the current $\operatorname{NAD}(\mathrm{P})$ $\mathrm{H}$ model. This feature perhaps is good for controlling the reaction enantioselectivity owing to the decrease in steric distance between the substrate and the catalyst. Based on our research on biomimetic asymmetric hydrogenation, ${ }^{7}$ the $\mathrm{Ru}(\mathrm{II})$ complex was chosen as the catalyst for the regeneration of DHPD 2 from phenanthridine 1 under hydrogen gas (Table 1).
$\left[\mathrm{Ru}(p \text {-cymene }) \mathrm{I}_{2}\right]_{2}$ exhibited similar catalytic efficiency in the reduction of phenanthridine 1 in different solvents under 200 psi of $\mathrm{H}_{2}$ (entries 1-6). No decrease of conversion was observed with the change of the pressure of $\mathrm{H}_{2}$, even under atmospheric pressure using $\mathrm{CH}_{2} \mathrm{Cl}_{2}$ as the solvent (entries 79).

Biomimetic Asymmetric Hydrogenation of Benzoxazinones. Subsequently, the feasibility of the in situ regeneration of DHPD for the asymmetric hydrogenation of benzoxazinone 3a was explored, and the results are presented in Table 2. ${ }^{10}$ The evaluation of chiral Brønsted acids demonstrated that $(S)-5 d$ was the best catalyst for the hydride transfer and delivered $4 \mathbf{a}$ in $94 \%$ ee (entries 1-4). ${ }^{11,12}$ No improvement of the conversion was achieved through the investigation of solvent effect (entries 5-8). With the increasing of the pressure of hydrogen gas or the catalyst loading, an improvement of reaction conversion was observed (entries 9-10). Prolonging the reaction time delivered the dihydrobenzoxazinone $4 \mathbf{a}$ with excellent conversion (entry 11).

With the optimized conditions, the generality of the biomimetic asymmetric hydrogenation of benzoxazinones 3 using a catalytic amount of phenanthridine 1 (10 mol \%) was investigated (Table 3). In general, moderate to excellent yields (77-96\%) and excellent enantioselectivities (87-97\% ee) were achieved in this hydrogenation system for various benzoxazinones 3 regardless of the electronic properties of substituents (entries 1 and 3-12). Interestingly, an unexpected reversal of enantioselectivity was observed between the different $\mathrm{NAD}(\mathrm{P}) \mathrm{H}$ models (DHPD vs $\mathrm{HEH}$ )-promoted biomimetic asymmetric hydrogenation (entry 1 vs 2). ${ }^{7 a, 10 a}$

Enantioreversal Phenomenon in Biomimetic Asymmetric Hydrogenation. The origin of enantioreversal in biomimetic asymmetric hydrogenation of benzoxazinones 3 can be explained by the stereochemical model as illustrated in Figure $2 .{ }^{13}$ For the biomimetic asymmetric hydrogenation promoted by DHPD, the substrate 3a and DHPD interact with chiral phosphoric acid $(S)-5$ through two hydrogen bonds (eq 1). ${ }^{14}$ These two hydrogen bonds and the effect of steric hindrance build up a "three-point contact model" that determines the stereoselectivity in this 1,2-hydride transfer process. In the biomimetic asymmetric hydrogenation promoted by $\mathrm{HEH}^{7 \mathrm{a}} 3 \mathrm{a} /(S)-5 / \mathrm{HEH}$ form another threepoint contact model leading to Re-face reduction based on Goodman and Himo's calculation (eq 2). ${ }^{15}$ The different steric

Table 1. Generation of DHPD 2 from Phenanthridine $1^{a}$

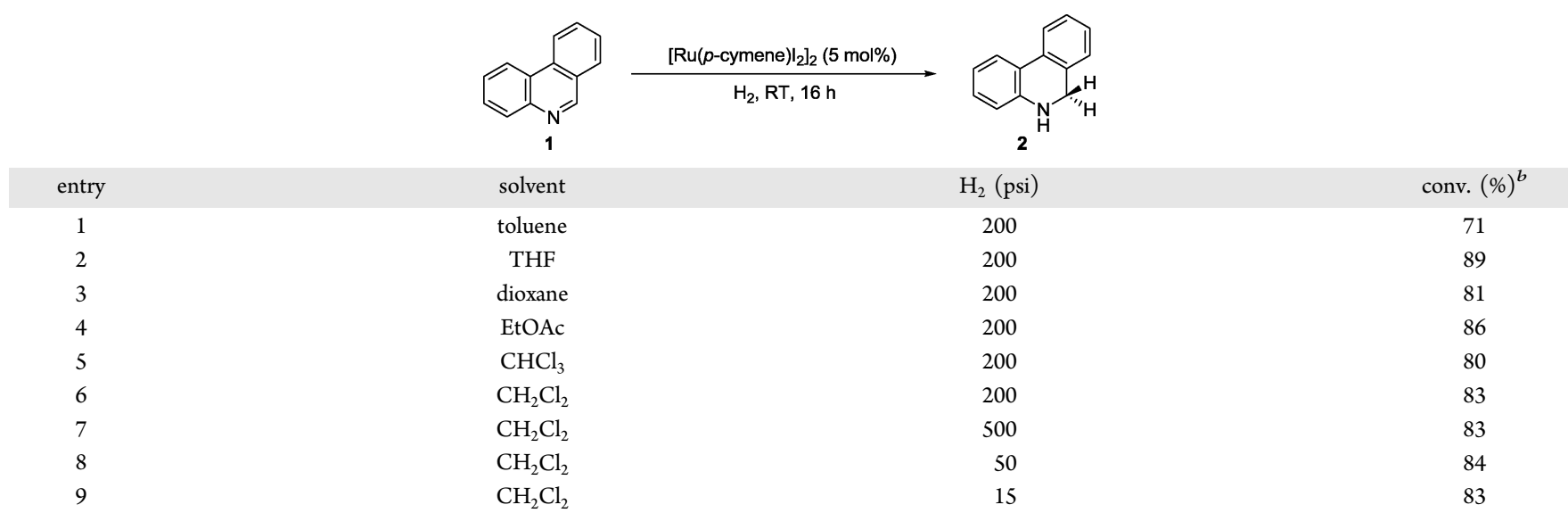

${ }^{a_{1}} 1(0.02 \mathrm{mmol}),\left[\mathrm{Ru}(p \text {-cymene }) \mathrm{I}_{2}\right]_{2}(5 \mathrm{~mol} \%), \mathrm{H}_{2}$, solvent $(2 \mathrm{~mL}), 16 \mathrm{~h} .{ }^{b}$ Determined by $1 \mathrm{H} \mathrm{NMR}$. 
Table 2. In Situ Regeneration of DHPD 2 for the Biomimetic Hydrogenation of Benzoxazinone $3 \mathrm{a}^{a}$

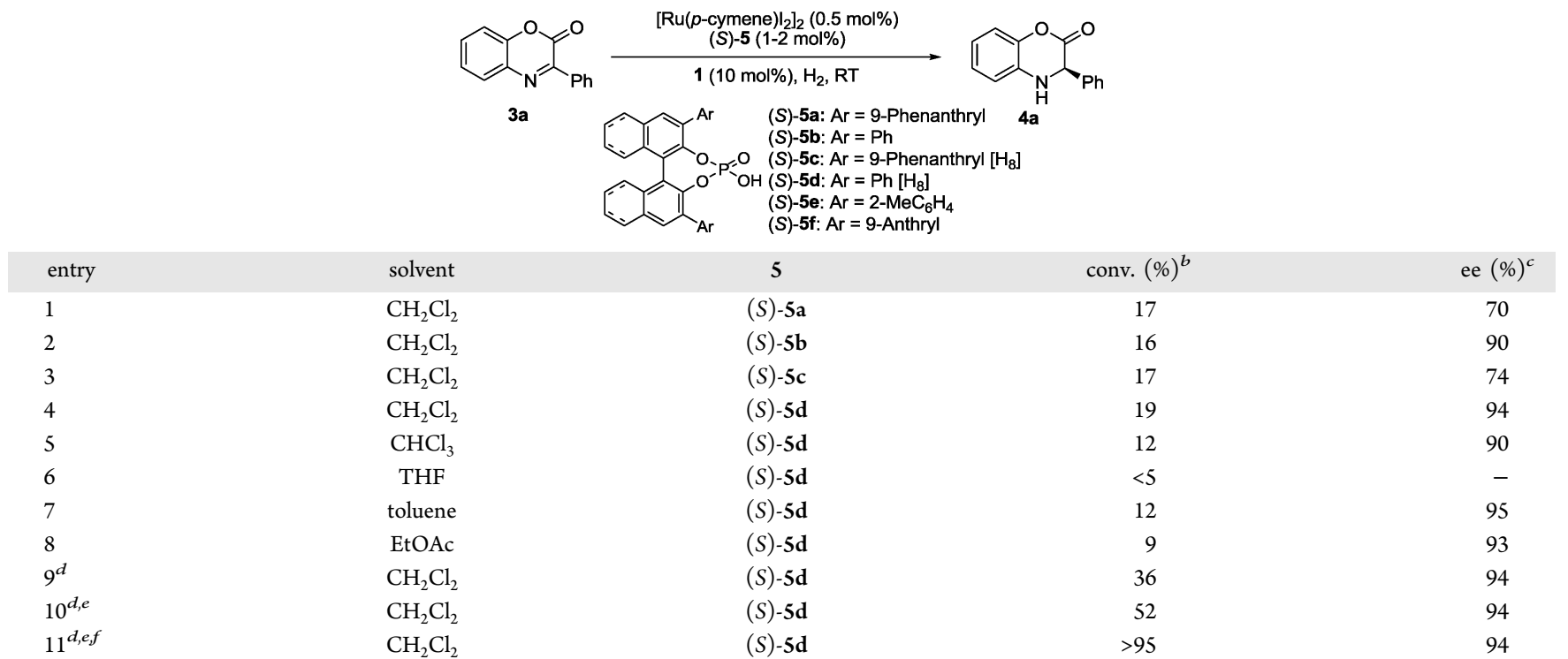

$a_{3 a}(0.20 \mathrm{mmol}), \mathbf{1}(10 \mathrm{~mol} \%),\left[\mathrm{Ru}(p \text {-cymene }) \mathrm{I}_{2}\right]_{2}(0.5 \mathrm{~mol} \%),(S)-5(1 \mathrm{~mol} \%)$, solvent $(2 \mathrm{~mL}), \mathrm{H}_{2}(50 \mathrm{psi}), 16 \mathrm{~h} .{ }^{b}$ Determined by ${ }^{1} \mathrm{H} \mathrm{NMR}$. ${ }^{c}$ Determined by HPLC. ${ }^{d} \mathrm{H}_{2}(500 \mathrm{psi}) .{ }^{e}(S)-5 \mathrm{~d}(2 \mathrm{~mol} \%) .{ }_{48} \mathrm{~h}$.

Table 3. Biomimetic Asymmetric Hydrogenation of Benzoxazinones 3 Using Phenanthridine $1^{a}$

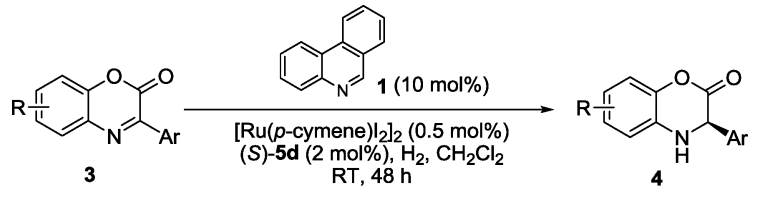

\begin{tabular}{|c|c|c|c|c|}
\hline entry & $\mathrm{R}$ in 3 & Ar in 3 & yield $(\%)^{b}$ & ee $(\%)^{c}$ \\
\hline 1 & $\mathrm{H}$ & $\mathrm{Ph}$ & $96(4 a)$ & $94(R)$ \\
\hline $2^{d}$ & $\mathrm{H}$ & $\mathrm{Ph}$ & $93(4 a)$ & $98(S)$ \\
\hline 3 & $\mathrm{H}$ & $4-\mathrm{MeOC}_{6} \mathrm{H}_{4}$ & $94(4 \mathbf{b})$ & $94(R)$ \\
\hline 4 & $\mathrm{H}$ & 4- $\mathrm{MeC}_{6} \mathrm{H}_{4}$ & $96(4 c)$ & $93(R)$ \\
\hline 5 & $\mathrm{H}$ & 3,4- $\mathrm{Me}_{2} \mathrm{C}_{6} \mathrm{H}_{3}$ & $94(4 d)$ & $90(R)$ \\
\hline 6 & $\mathrm{H}$ & 4- $\mathrm{ClC}_{6} \mathrm{H}_{4}$ & $89(4 e)$ & $96(R)$ \\
\hline 7 & $\mathrm{H}$ & 4- $\mathrm{BrC}_{6} \mathrm{H}_{4}$ & $82(4 f)$ & $97(R)$ \\
\hline 8 & $\mathrm{H}$ & $4-\mathrm{FC}_{6} \mathrm{H}_{4}$ & $82(4 \mathrm{~g})$ & $95(R)$ \\
\hline 9 & $\mathrm{H}$ & $3-\mathrm{FC}_{6} \mathrm{H}_{4}$ & $82(4 h)$ & $94(R)$ \\
\hline 10 & $\mathrm{H}$ & 2-thienyl & $78(4 \mathbf{i})$ & $95(S)$ \\
\hline 11 & 6-Cl & $\mathrm{Ph}$ & $87(\mathbf{4 j})$ & $89(R)$ \\
\hline 12 & 6-Me & $\mathrm{Ph}$ & $77(4 \mathrm{k})$ & $87(R)$ \\
\hline 13 & 7-Me & $\mathrm{Ph}$ & $90(4 \mathbf{l})$ & $93(R)$ \\
\hline
\end{tabular}

$a_{3}(0.20 \mathrm{mmol}), \mathbf{1}(10 \mathrm{~mol} \%),\left[\mathrm{Ru}(p \text {-cymene }) \mathrm{I}_{2}\right]_{2}(0.5 \mathrm{~mol} \%),(S)-5 \mathrm{~d}(2 \mathrm{~mol} \%), \mathrm{H}_{2}(500 \mathrm{psi}), \mathrm{CH}_{2} \mathrm{Cl}_{2}(2 \mathrm{~mL}), 48 \mathrm{~h}, \mathrm{RT} .{ }^{b}$ Isolated yields. ${ }^{c}$ Determined by HPLC. ${ }^{d}$ The data were quoted from ref $7 \mathrm{a}: 3(0.20 \mathrm{mmol})$, Hantzsch ethyl ester $(10 \mathrm{~mol} \%),\left[\mathrm{Ru}(p \text {-cymene }) \mathrm{I}_{2}\right]_{2}(1.25 \mathrm{~mol} \%),(S)$ 5a $(2 \mathrm{~mol} \%), \mathrm{H}_{2}(1000 \mathrm{psi}), \mathrm{THF} / \mathrm{CH}_{2} \mathrm{Cl}_{2} \mathrm{l} / 3(2 \mathrm{~mL}), 48 \mathrm{~h}, 50{ }^{\circ} \mathrm{C}$.

demand between 1,2- and 1,4-hydride transfer pathway is responsible for the reversal of enantioselectivity which we had observed in the asymmetric disproportionation of dihydroquinoxalines. $^{7 \mathrm{~b}}$

Biomimetic Asymmetric Hydrogenation of Benzoxazines. Encouraged by the successful hydrogenation of benzoxazinones 3 , we then examined the hydrogenation of benzoxazines 6 . The pressure of $\mathrm{H}_{2}$ could be further reduced in the biomimetic asymmetric reduction of benzoxazines 6 using a catalytic amount of phenanthridine 1 (10 mol \%) with full conversion and up to $92 \%$ ee (Table 4, entries 1 and 4-11). ${ }^{16}$ Even under $1 \mathrm{~atm}$ of $\mathrm{H}_{2}$, full conversion was observed in the reduction of benzoxazine 6a with $2 \mathrm{~mol} \%$ of $[\mathrm{Ru}(p$ cymene $\left.\mathrm{I}_{2}\right]_{2}$ in $72 \mathrm{~h}$ (entry 2). As expected, a reversal of enantioselectivity was also observed in the reduction of benzoxazines 6 promoted by different hydride transfer reagents (DHPD vs HEH, entry 1 vs 3 ). Notably, the obtained chiral products dihydrobenzoxazines 7 are efficient catalysts for the enantioselective transfer hydrogenation of $\alpha, \beta$-unsaturated aldehydes with Hantzsch esters as hydrogen source. ${ }^{16 c}$

Biomimetic Asymmetric Hydrogenation of Aromatic Compounds Quinoxalines. The biomimetic asymmetric hydrogenation promoted by DHPD could also be successfully applied to the reduction of aromatic compounds, ${ }^{17}$ such as quinoxalines $^{18,19}$ and quinolines. ${ }^{20,21}$ The optically pure $1,2,3,4-$ tetrahydroquinoxaline derivatives are of great synthetic potential in the preparation of pharmaceuticals and agrochemicals. Therefore, various transitional metal catalysts 
DHPD-Promoted Transfer Hydrogenation (1,2 H-transfer)

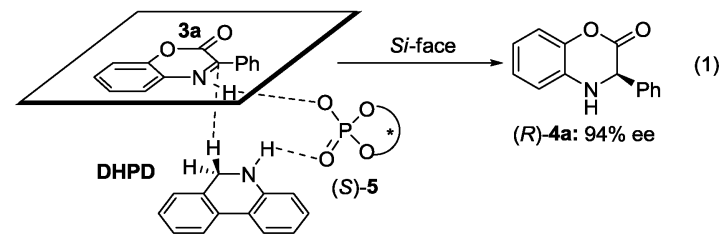

HEH-Promoted Transfer Hydrogenation (1,4 H-transfer)

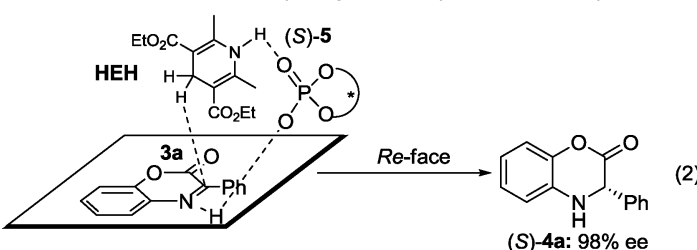

(S)-4a: $98 \%$ ee

Figure 2. Origin of enantioreversal in the biomimetic asymmetric hydrogenation resulting from different hydride transfer pathways.

involving rhodium, iridium, and ruthenium complexes have been developed for the enantioselective hydrogenation of quinoxalines since 1987. ${ }^{18}$ Recently, Rueping and co-workers reported highly enantioselective Brønsted acid-catalyzed transfer hydrogenation of quinoxalines with $\mathrm{HEH}$ as hydrogen source. ${ }^{19}$ Owing to the fact that there are two unsaturated bonds $(\mathrm{C}=\mathrm{N})$ reduced in quinoxalines, at least 2 equiv of Hantzsch esters are required in order to achieve full conversion. Besides this, separating the chiral products from the pyridine derivatives (more than 2 equiv) generated by dehydrogenation of Hantzsch ester is difficult. These two disadvantages will be overcome by the biomimetic asymmetric hydrogenation of quinoxalines 8 promoted by a catalytic amount of phenanthridine 1.

The optimized condition was obtained through an exploration of appropriate Brønsted acid catalysts and the examination of reaction parameters, such as solvent, hydrogen gas pressure, catalyst loading, and temperature. Only $10 \mathrm{~mol} \%$ of phenanthridine $\mathbf{1}$ was required to promote the hydro- genation of the two double bonds $(\mathrm{C}=\mathrm{N})$ in the moiety of quinoxalines 8 with high yields (Table 5). Generally, good to excellent enantioselectivities $(85-95 \%)$ were obtained in this biomimetic asymmetric hydrogenation system regardless of the electronic property of the substituent on quinoxalines $\mathbf{8}$ (entries 1 and 3-12). As predicted, an enantioreversal phenomenon occurred once again (entry 1 vs 2 ).

Biomimetic Asymmetric Hydrogenation of Aromatic Compounds Quinolines. In 2003, our group developed the first example of iridium-catalyzed highly enantioselective hydrogenation of quinolines providing a simple access to chiral 1,2,3,4-tetrahydroquinolines, which are of great synthetic importance in the preparation of natural products and pharmaceuticals. ${ }^{8 \mathrm{a}-\mathrm{f}}$ Subsequently, much important progress has been achieved in the asymmetric hydrogenation of quinolines using numerous transition-metal catalysts. ${ }^{20}$ Meanwhile, the organocatalytic asymmetric transfer hydrogenation of quinolines using Hantzsch esters as hydrogen source has been well developed by Rueping and $\mathrm{Du}^{21}$

Due to the fact that two different unsaturated double bonds $(\mathrm{C}=\mathrm{C}$ and $\mathrm{C}=\mathrm{N})$ are reduced in quinolines, the biomimetic asymmetric hydrogenation of quinolines $\mathbf{1 0}$ will be more difficult than the hydrogenation of quinoxalines considering the catalyst system's selectivities. In order to achieve high conversions, the catalyst loading, hydrogen gas pressure, and reaction temperature have to be increased (Table 6). To our delight, excellent enantioselectivities (86-93\%) could also be obtained in the biomimetic asymmetric hydrogenation of quinolines 10 using a catalytic amount of phenanthridine 1 (entries 1-8).

Proposed Catalytic Cycle for Biomimetic Asymmetric Hydrogenation. A proposed mechanism for the biomimetic asymmetric hydrogenation of imines is illustrated in Scheme 3. Just like the enzymatic reactions where $\mathrm{NAD}(\mathrm{P}) \mathrm{H}$ is involved, this biomimetic asymmetric hydrogenation comprises two cascade redox cycles promoted by metal/Brønsted acid relay catalysis. $^{22}$ Owing to the easy regeneration of DHPD 2 from phenanthridine 1, a milder reaction condition was required

Table 4. Biomimetic Asymmetric Hydrogenation of Benzoxazines 6 Using Phenanthridine 1 under Mild Conditions ${ }^{a}$

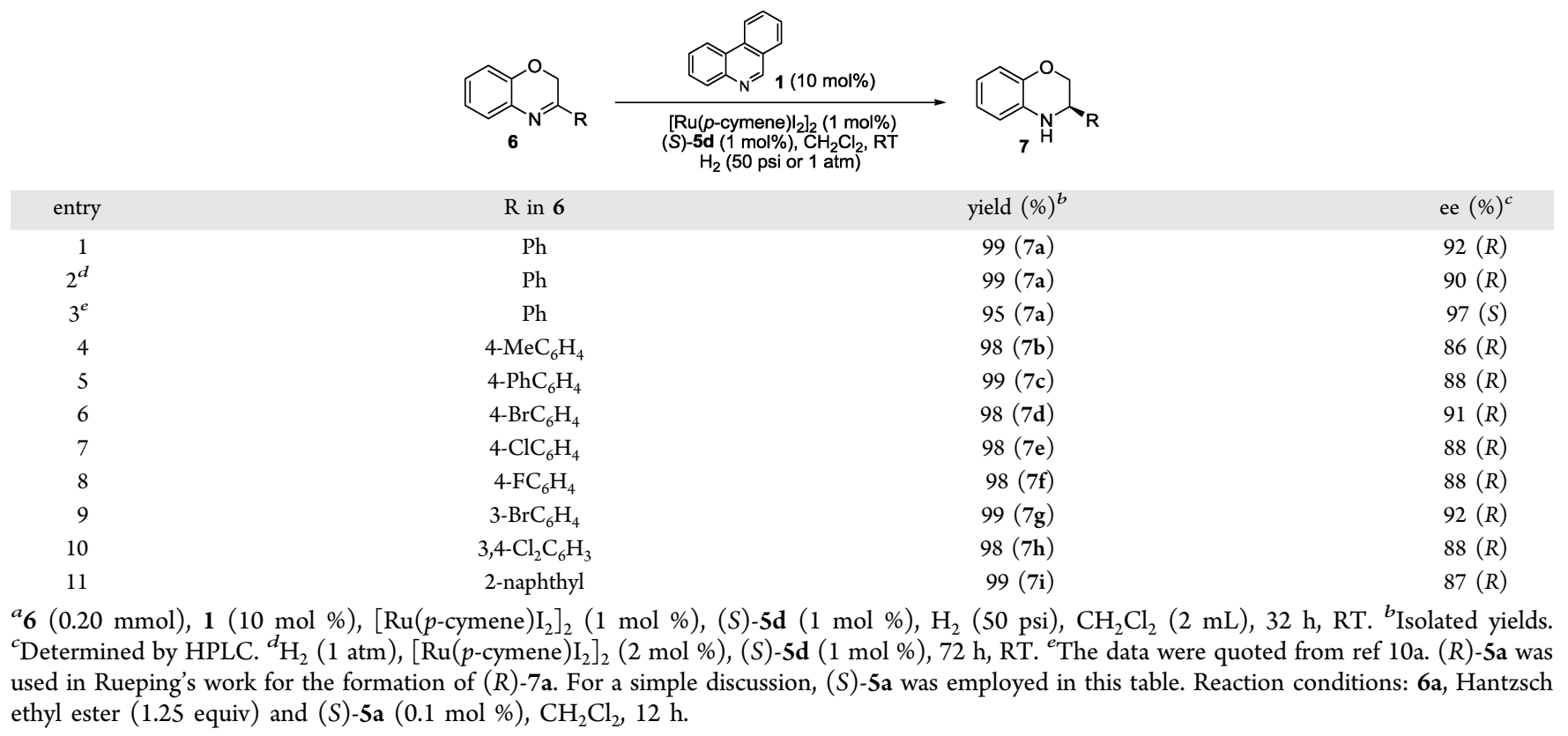


Table 5. Biomimetic Asymmetric Hydrogenation of Quinoxalines 8 Using Phenanthridine $1^{a}$

\begin{tabular}{|c|c|c|c|}
\hline entry & $\mathrm{Ar}$ in 8 & yield $(\%)^{b}$ & ee $(\%)^{c}$ \\
\hline 1 & $\mathrm{Ph}$ & $99(9 a)$ & $90(R)$ \\
\hline $2^{d}$ & $\mathrm{Ph}$ & $98(9 a)$ & $90(S)$ \\
\hline 3 & 4- $\mathrm{MeC}_{6} \mathrm{H}_{4}$ & $96(9 b)$ & $91(R)$ \\
\hline 4 & $4-\mathrm{MeOC}_{6} \mathrm{H}_{4}$ & $98(9 c)$ & $85(R)$ \\
\hline 5 & 4- $\mathrm{FC}_{6} \mathrm{H}_{4}$ & $98(9 d)$ & $91(R)$ \\
\hline 6 & 4- $\mathrm{ClC}_{6} \mathrm{H}_{4}$ & $98(9 e)$ & $91(R)$ \\
\hline 7 & 4- $\mathrm{BrC}_{6} \mathrm{H}_{4}$ & 98 (9f) & $92(R)$ \\
\hline 8 & 4- $\mathrm{CF}_{3} \mathrm{C}_{6} \mathrm{H}_{4}$ & $93(9 \mathrm{~g})$ & $93(R)$ \\
\hline 9 & $3-\mathrm{FC}_{6} \mathrm{H}_{4}$ & $99(9 \mathbf{h})$ & $90(R)$ \\
\hline 10 & 3- $\mathrm{ClC}_{6} \mathrm{H}_{4}$ & $96(9 \mathrm{i})$ & $92(R)$ \\
\hline 11 & $3-\mathrm{BrC}_{6} \mathrm{H}_{4}$ & $99(9 \mathbf{j})$ & $93(R)$ \\
\hline 12 & 2-naphthyl & $96(9 k)$ & $95(R)$ \\
\hline
\end{tabular}

${ }^{a} 8(0.20 \mathrm{mmol}), \mathbf{1}(10 \mathrm{~mol} \%),\left[\mathrm{Ru}(p \text {-cymene }) \mathrm{I}_{2}\right]_{2}$ (0.5 mol \%), (S)-5e (1 mol \%), $\mathrm{H}_{2}(100 \mathrm{psi})$, benzene $(2 \mathrm{~mL}), 48 \mathrm{~h}, \mathrm{RT} .{ }^{b}$ Isolated yields. ${ }^{c}$ Determined by HPLC. ${ }^{d}$ The data were quoted from ref 19 . (R)-5f was used in Rueping's work for the formation of $(R)-9 \mathrm{a}$. For a simple discussion, $(S)$-5f was employed in this table. Reaction conditions: 8, Hantzsch ethyl ester (2.4 equiv) and $(S)-5 f(10 \mathrm{~mol} \%), 35{ }^{\circ} \mathrm{C}, \mathrm{CHCl}_{3}(0.5 \mathrm{M}), 24 \mathrm{~h}$.

Table 6. Biomimetic Asymmetric Hydrogenation of Quinolines 10 Using Phenanthridine $1^{a}$

\begin{tabular}{|c|c|c|c|}
\hline entry & Ar in 10 & yield $(\%)^{b}$ & ee $(\%)^{c}$ \\
\hline 1 & $\mathrm{Ph}$ & 95 (11a) & $91(S)$ \\
\hline 2 & 4- $\mathrm{MeC}_{6} \mathrm{H}_{4}$ & $96(\mathbf{1 1 b})$ & $90(S)$ \\
\hline 3 & 4- $\mathrm{MeOC}_{6} \mathrm{H}_{4}$ & $98(11 c)$ & $86(S)$ \\
\hline 4 & 4- $-\mathrm{FC}_{6} \mathrm{H}_{4}$ & $96(11 d)$ & $90(S)$ \\
\hline 5 & $4-\mathrm{ClC}_{6} \mathrm{H}_{4}$ & $94(11 \mathrm{e})$ & $91(S)$ \\
\hline 6 & 4- $\mathrm{BrC}_{6} \mathrm{H}_{4}$ & 90 (11f) & $93(S)$ \\
\hline 7 & 4- $\mathrm{CF}_{3} \mathrm{C}_{6} \mathrm{H}_{4}$ & $64(11 \mathrm{~g})^{d}$ & $92(S)$ \\
\hline 8 & 2-naphthyl & $92(11 \mathrm{~h})$ & $91(S)$ \\
\hline
\end{tabular}

${ }^{a} 10(0.20 \mathrm{mmol}), \mathbf{1}(10 \mathrm{~mol} \%),\left[\mathrm{Ru}(p \text {-cymene }) \mathrm{I}_{2}\right]_{2}(0.5 \mathrm{~mol} \%),(\mathrm{S})-5 \mathrm{e}(4 \mathrm{~mol} \%), \mathrm{H}_{2}(400 \mathrm{psi})$, benzene $(2 \mathrm{~mL}), 40{ }^{\circ} \mathrm{C}, 48 \mathrm{~h}, \mathrm{RT}$. ${ }^{b} \mathrm{Isolated}$ yields. ${ }^{c}$ Determined by HPLC. ${ }^{d}$ Conversion determined by ${ }^{1} \mathrm{H}$ NMR.

Scheme 3. Proposed Mechanism for Biomimetic Hydrogenation of Imines Using Phenanthridine 1 (CPA = Chiral Phosphoric Acid)

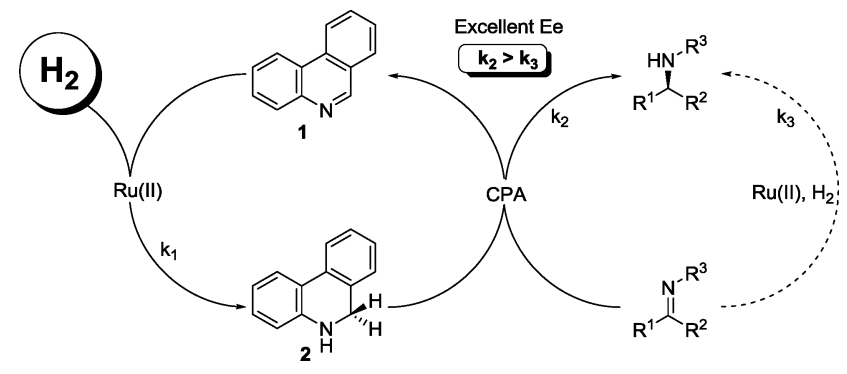

compared with the biomimetic asymmetric hydrogenation using a catalytic amount of $\mathrm{HEH}^{7 \mathrm{a}}$ The excellent enantioselectivities achieved in this biomimetic asymmetric transfer hydrogenation are attributed to the fact that the reaction rate of this principal reaction $k_{2}$ is faster than that of the undesired side reaction $k_{3}$ which gives racemic products.

\section{CONCLUSIONS}

In summary, we have successfully developed a new and easily regenerable $\mathrm{NAD}(\mathrm{P}) \mathrm{H}$ model $\mathrm{DHPD}$ for biomimetic asymmetric hydrogenation of benzoxazinones, benzoxazines, quinoxalines, and quinolines. The easy regeneration of DHPD 2 from phenanthridine 1 suggests that this biomimetic cascade reduction could be performed under mild conditions. Therefore, the substrate scope is not limited in benzoxazinones; the biomimetic asymmetric hydrogenation of benzoxazines, quinoxalines, and quinolines also gave excellent activities and enantioselectivities. Meanwhile, an unexpected reversal of enantioselectivity was observed between the reactions promoted by the different $\mathrm{NAD}(\mathrm{P}) \mathrm{H}$ models. This work also features the use of hydrogen gas as the terminal reductant for the regeneration of the $\mathrm{NAD}(\mathrm{P}) \mathrm{H}$ model and combining transition-metal catalyst and organocatalyst for two biomimetic cascade redox cycles. Further investigations on the application of this method are currently ongoing in our lab. 


\section{ASSOCIATED CONTENT}

\section{S Supporting Information}

Complete experimental procedures and characterization data for the prepared compounds. This material is available free of charge via the Internet at http://pubs.acs.org.

\section{AUTHOR INFORMATION}

\section{Corresponding Author}

ygzhou@dicp.ac.cn

\section{ACKNOWLEDGMENTS}

This work was supported by the National Natural Science Foundation of China (21032003 and 21125208), National Basic Research Program of China (2010CB833300), and Dalian Institute of Chemical Physics (K2010F1). We also thank Prof. Xumu Zhang of Rutgers University and Prof. WenJing Xiao of Central China Normal University for very helpful discussions.

\section{REFERENCES}

(1) (a) Lin, H. Org. Biomol. Chem. 2007, 5, 2541. (b) Ying, W. H. Antioxid. Redox Signal. 2008, 10, 179. (c) Houtkooper, R. H.; Cantó, C.; Wanders, R. J.; Auwerx, J. Endocr. Rev. 2010, 31, 194.

(2) For selected work on regeneration of $\mathrm{NAD}(\mathrm{P}) \mathrm{H}$ models, see: (a) Lo, H. C.; Fish, R. H. Angew. Chem., Int. Ed. 2002, 41, 478. (b) Wagenknecht, P. S.; Penney, J. M.; Hembre, R. T. Organometallics 2003, 22, 1180. (c) Xu, H. J.; Liu, Y. C.; Fu, Y.; Wu, Y. D. Org. Lett. 2006, 8, 3449. (d) Procuranti, B.; Connon, S. J. Chem. Commun. 2007, 1421.

(3) For recent reviews on asymmetric reactions using Hantzsch esters, see: (a) Ouellet, S. G.; Walji, A. M.; MacMillan, D. W. C. Acc. Chem. Res. 2007, 40, 1327. (b) You, S. L. Chem. Asian J. 2007, 2, 820. (c) Connon, S. J. Org. Biomol. Chem. 2007, 5, 3407. (d) Rueping, M.; Dufour, J.; Schoepke, F. R. Green Chem. 2011, 13, 1084.

(4) For recent work on chiral Brønsted acids catalyzed asymmetric transfer hydrogenation with Hantzsch esters, see: (a) Singh, S.; Batra, U. K. Indian J. Chem., Sect. B: Org. Chem. Incl. Med. Chem. 1989, 28, 1. (b) Rueping, M.; Sugiono, E.; Azap, C.; Theissmann, T.; Bolte, M. Org. Lett. 2005, 7, 3781. (c) Hoffmann, S.; Seayad, A. M.; List, B. Angew. Chem., Int. Ed. 2005, 44, 7424. (d) Martin, N. J. A.; List, B. J. Am. Chem. Soc. 2006, 128, 13368. (e) Mayer, S.; List, B. Angew. Chem., Int. Ed. 2006, 45, 4193. (f) Kang, Q.; Zhao, Z. A.; You, S. L. Adv. Synth. Catal. 2007, 349, 1657. (g) Li, G. L.; Liang, Y. X.; Antilla, J. C. J. Am. Chem. Soc. 2007, 129, 5830. (h) Rueping, M.; Antonchick, A. P. Angew. Chem., Int. Ed. 2007, 46, 4562. (i) Zhou, J.; List, B. J. Am. Chem. Soc. 2007, 129, 7498. (j) Kang, Q.; Zhao, Z. A.; You, S. L. Org. Lett. 2008, 10, 2031. (k) Li, G. L.; Antilla, J. C. Org. Lett. 2009, 11, 1075. (1) Han, Z. Y.; Xiao, H.; Chen, X. H.; Gong, L. Z. J. Am. Chem. Soc. 2009, 131, 9182. (m) Liu, X. Y.; Che, C. M. Org. Lett. 2009, 11, 4204. (n) Nguyen, T. B.; Bousserouel, H.; Wang, Q.; Guéritte, F. Org. Lett. 2010, 12, 4705. (o) Rueping, M.; Brinkmann, C.; Antonchick, A. P.; Atodiresei, I. Org. Lett. 2010, 12, 4604. (p) Rueping, M.; Merino, E.; Koenigs, R. M. Adv. Synth. Catal. 2010, 352, 2629. (q) Wakchaure, V. N.; Zhou, J.; Hoffmann, S.; List, B. Angew. Chem., Int. Ed. 2010, 49, 4612. (r) Nguyen, T. B.; Bousserouel, H.; Wang, Q.; Guéritte, F. Adv. Synth. Catal. 2011, 353, 257. (s) Nguyen, T. B.; Wang, Q.; Guéritte, F. Chem.-Eur. J. 2011, 17, 9576.

(5) For selected work on chiral amine promoted asymmetric transfer hydrogenation with Hantzsch esters, see: (a) Yang, J. W.; Hechavarria Fonseca, M. T.; List, B. Angew. Chem., Int. Ed. 2004, 43, 6660. (b) Ouellet, S. G.; Tuttle, J. B.; MacMillan, D. W. C. J. Am. Chem. Soc. 2005, 127, 32. (c) Yang, J. W.; Hechavarria Fonseca, M. T.; Vignola, N.; List, B. Angew. Chem., Int. Ed. 2005, 44, 108. (d) Tuttle, J. B.; Ouellet, S. G.; MacMillan, D. W. C. J. Am. Chem. Soc. 2006, 128, 12662. (e) Zhao, G. L.; Córdova, A. Tetrahedron Lett. 2006, 47, 7417. (f) Akagawa, K.; Akabane, H.; Sakamoto, S.; Kudo, K. Org. Lett. 2008,
10, 2035. For selected work on chiral thiourea-catalyzed asymmetric transfer hydrogenation with Hantzsch esters, see: (g) Martin, N. J. A.; Ozores, L.; List, B. J. Am. Chem. Soc. 2007, 129, 8976. (h) Martin, N. J. A.; Cheng, X.; List, B. J. Am. Chem. Soc. 2008, 130, 13862. (i) Schneider, J. F.; Lauber, M. B.; Muhr, V.; Kratzer, D.; Paradies, J. Org. Biomol. Chem. 2011, 9, 4323.

(6) For selected work on metal-catalyzed asymmetric transfer hydrogenation with Hantzsch esters, see: (a) Zehani, S.; Gelbard, G. J. Chem. Soc., Chem. Commun. 1985, 1162. (b) Yang, J. W.; List, B. Org. Lett. 2006, 8, 5653. (c) Wang, D. W.; Zeng, W.; Zhou, Y. G. Tetrahedron: Asymmetry 2007, 18, 1103.

(7) (a) Chen, Q. A.; Chen, M. W.; Yu, C. B.; Shi, L.; Wang, D. S.; Yang, Y.; Zhou, Y. G. J. Am. Chem. Soc. 2011, 133, 16432. (b) Chen, Q. A.; Wang, D. S.; Zhou, Y. G.; Duan, Y.; Fan, H. J.; Yang, Y.; Zhang, Z. J. Am. Chem. Soc. 2011, 133, 6126.

(8) For selected work from our group on asymmetric hydrogenation and transfer hydrogenation, see quinolines: (a) Wang, W. B.; Lu, S. M.; Yang, P. Y.; Han, X. W.; Zhou, Y. G. J. Am. Chem. Soc. 2003, 125, 10536. (b) Lu, S. M.; Han, X. W.; Zhou, Y. G. Adv. Synth. Catal. 2004, 346, 909. (c) Lu, S. M.; Wang, Y. Q.; Han, X. W.; Zhou, Y. G. Angew. Chem., Int. Ed. 2006, 45, 2260. (d) Wang, D. W.; Wang, X. B.; Wang, D. S.; Lu, S. M.; Zhou, Y. G.; Li, Y. X. J. Org. Chem. 2009, 74, 2780. (e) Wang, D. W.; Wang, D. S.; Chen, Q. A.; Zhou, Y. G. Chem.-Eur. J. 2010, 16, 1133. Pyridines: (f) Wang, X. B.; Zeng, W.; Zhou, Y. G. Tetrahedron Lett. 2008, 49, 4922. Indoles: (g) Wang, D. S.; Chen, Q. A.; Li, W.; Yu, C. B.; Zhou, Y. G.; Zhang, X. M. J. Am. Chem. Soc. 2010, 132, 8909. Pyrroles: (h) Wang, D. S.; Ye, Z. S.; Chen, Q. A.; Zhou, Y. G.; Yu, C. B.; Fan, H. J.; Duan, Y. J. Am. Chem. Soc. 2011, 133, 8866.

(9) For selected work on BNAH, see: (a) Lo, H. C.; Buriez, O.; Kerr, J. B.; Fish, R. H. Angew. Chem., Int. Ed. 1999, 38, 1429. (b) Konno, H.; Sakamoto, K.; Ishitani, O. Angew. Chem., Int. Ed. 2000, 39, 4061. (c) Fukuzumi, S.; Inada, O.; Suenobu, T. J. Am. Chem. Soc. 2003, 125, 4808. (d) Richter, D.; Mayr, H. Angew. Chem., Int. Ed. 2009, 48, 1958. (e) Matsubara, Y.; Koga, K.; Kobayashi, A.; Konno, H.; Sakamoto, K.; Morimoto, T.; Ishitani, O. J. Am. Chem. Soc. 2010, 132, 10547. For selected work on other $\mathrm{NAD}(\mathrm{P}) \mathrm{H}$ models, see: (f) Ohno, A.; Ishikawa, Y.; Yamazaki, N.; Okamura, M.; Kawai, Y. J. Am. Chem. Soc. 1998, 120, 1186. (g) Kanomata, N.; Nakata, T. J. Am. Chem. Soc. 2000, 122, 4563. (h) Zhang, B. L.; Zhu, X. Q.; Lu, J. Y.; He, J. Q.; Wang, P. G.; Cheng, J. P. J. Org. Chem. 2003, 68, 3295. (i) Wang, N. X.; Zhao, J. Synlett 2007, 2785.

(10) For recent work on asymmetric reduction of benzoxazinones, see: (a) Rueping, M.; Antonchick, A. P.; Theissmann, T. Angew. Chem., Int. Ed. 2006, 45, 6751. (b) Storer, R. I.; Carrera, D. E.; Ni, Y.; MacMillan, D. W. C. J. Am. Chem. Soc. 2006, 128, 84. (c) Xue, Z. Y.; Jiang, Y.; Peng, X. Z.; Yuan, W. C.; Zhang, X. M. Adv. Synth. Catal. 2010, 352, 2132.

(11) For recent work on asymmetric hydrogenation assisted by chiral phosphoric acids, see: (a) Li, C. Q.; Wang, C.; Villa-Marcos, B.; Xiao, J. L. J. Am. Chem. Soc. 2008, 130, 14450. (b) Li, C. Q.; Villa-Marcos, B.; Xiao, J. L. J. Am. Chem. Soc. 2009, 131, 6967. (c) Rueping, M.; Koenigs, R. M. Chem. Commun. 2011, 47, 304. (d) Zhou, S.; Fleischer, S.; Junge, K.; Beller, M. Angew. Chem., Int. Ed. 2011, 50, 5120.

(12) For recent reviews on chiral phosphoric acids, see: (a) Akiyama, T. Chem. Rev. 2007, 107, 5744. (b) Kampen, D.; Reisinger, C. M.; List, B. Top. Curr. Chem. 2010, 291, 395. (c) Terada, M. Synthesis 2010, 1929. (d) Zamfir, A.; Schenker, S.; Freund, M.; Tsogoeva, S. B. Org. Biomol. Chem. 2010, 8, 5262.

(13) Bartók, M. Chem. Rev. 2010, 110, 1663.

(14) No product was observed when $N$-methyl dihydrophenanthridine (stoichiometric amount) was used as hydrogen source in the (S)-5d-catalyzed transfer hydrogenation of benzoxazinone 3a at room temperature after $16 \mathrm{~h}$. This result suggests that the $\mathrm{N}-\mathrm{H}$ in DHPD 2 is crucial for the realization of the biomimetic asymmetric hydrogenation. A similar phenomenon was also observed in our previous work; see ref $7 \mathrm{~b}$.

(15) (a) Simón, L.; Goodman, J. M. J. Am. Chem. Soc. 2008, 130, 8741. (b) Marcelli, T.; Hammar, P.; Himo, F. Chem.-Eur. J. 2008, 14, 8562. 
(16) For recent work on asymmetric reduction of benzoxazines, see ref 10a and (a) Rueping, M.; Sugiono, E.; Steck, A.; Theissmann, T. Adv. Synth. Catal. 2010, 352, 281. (b) Bleschke, C.; Schmidt, J.; Kundu, D. S.; Blechert, S.; Thomas, A. Adv. Synth. Catal. 2011, 353, 3101. Dihydrobenzoxazines were used as catalysts: (c) Ebner, C.; Pfaltz, A. Tetrahedron 2011, 67, 10287.

(17) For recent reviews on asymmetric hydrogenation of aromatic compounds, see: (a) Glorius, F. Org. Biomol. Chem. 2005, 3, 4171. (b) Zhou, Y. G. Acc. Chem. Res. 2007, 40, 1357. (c) Kuwano, R. Heterocycles 2008, 76, 909. (d) Wang, D. S.; Chen, Q. A.; Lu, S. M.; Zhou, Y. G. Chem. Rev. 2011, DOI: 10.1021/cr200328h.

(18) For transition-metal-catalyzed asymmetric reduction of quinoxalines, see: (a) Murata, S.; Sugimoto, T.; Matsuura, S. Heterocycles 1987, 26, 763. (b) Bianchini, C.; Barbaro, P.; Scapacci, G.; Farnetti, E.; Graziani, M. Organometallics 1998, 17, 3308. (c) Cobley, C. J.; Henschke, J. P. Adv. Synth. Catal. 2003, 345, 195. (d) Mršić, N.; Jerphagnon, T.; Minnaard, A. J.; Feringa, B. L.; de Vries, J. G. Adv. Synth. Catal. 2009, 351, 2549. (e) Tang, W. J.; Xu, L. J.; Fan, Q. H.; Wang, J.; Fan, B. M.; Zhou, Z. Y.; Lam, K. H.; Chan, A. S. C. Angew. Chem., Int. Ed. 2009, 48, 9135. (f) Cartigny, D.; Nagano, T.; Ayad, T.; Genet, J. P.; Ohshima, T.; Mashima, K.; Ratovelomanana-Vidal, V. Adv. Synth. Catal. 2010, 352, 1886. (g) Qin, J.; Chen, F.; Ding, Z.; He, Y. M.; Xu, L.; Fan, Q. H. Org. Lett. 2011, 13, 6568.

(19) For organocatalyticasymmetric reduction of quinoxalines, see: Rueping, M.; Tato, F.; Schoepke, F. R. Chem.-Eur. J. 2010, 16, 2688. (20) For selected work on transition-metal-catalyzed asymmetric reduction of quinolines, see: refs $8 \mathrm{a}-\mathrm{e}$ and (a) Lam, K. H.; Xu, L. J.; Feng, L. C.; Fan, Q. H.; Lam, F. L.; Lo, W. H.; Chan, A. S. C. Adv. Synth. Catal. 2005, 347, 1755. (b) Xu, L. J.; Lam, K. H.; Ji, J. X.; Wu, J.; Fan, Q. H.; Lo, W. H.; Chan, A. S. C. Chem. Commun. 2005, 1390. (c) Reetz, M. T.; Li, X. G. Chem. Commun. 2006, 2159. (d) Wang, Z. J.; Deng, G. J.; Li, Y.; He, Y. M.; Tang, W. J.; Fan, Q. H. Org. Lett. 2007, 9, 1243. (e) Li, Z. W.; Wang, T. L.; He, Y. M.; Wang, Z. J.; Fan, Q. H.; Pan, J.; Xu, L. J. Org. Lett. 2008, 10, 5265. (f) Lu, S. M.; Bolm, C. Adv. Synth. Catal. 2008, 350, 1101. (g) Mršić, N.; Lefort, L.; Boogers, J. A. F.; Minnaard, A. J.; Feringa, B. L.; de Vries, J. G. Adv. Synth. Catal. 2008, 350, 1081. (h) Zhou, H. F.; Li, Z. W.; Wang, Z. J.; Wang, T. L.; Xu, L. J.; He, Y.; Fan, Q. H.; Pan, J.; Gu, L. Q.; Chan, A. S. C. Angew. Chem., Int. Ed. 2008, 47, 8464. (i) Tadaoka, H.; Cartigny, D.; Nagano, T.; Gosavi, T.; Ayad, T.; Genet, J. P.; Ohshima, T.; Ratovelomanana-Vidal, V.; Mashima, K. Chem.-Eur. J. 2009, 15, 9990. (j) Wang, C.; Li, C. Q.; Wu, X. F.; Pettman, A.; Xiao, J. L. Angew. Chem., Int. Ed. 2009, 48, 6524. (k) Núñez-Rico, J. L.; Fernández-Pérez, H.; Benet-Buchholz, J.; Vidal-Ferran, A. Organometallics 2010, 29, 6627. (1) Wang, T.; Zhuo, L. G.; Li, Z.; Chen, F.; Ding, Z.; He, Y.; Fan, Q. H.; Xiang, J.; Yu, Z. X.; Chan, A. S. C. J. Am. Chem. Soc. 2011, 133, 9878.

(21) For recent work on organocatalytic asymmetric reduction of quinolines, see: (a) Rueping, M.; Antonchick, A. R.; Theissmann, T. Angew. Chem., Int. Ed. 2006, 45, 3683. (b) Guo, Q. S.; Du, D. M.; Xu, J. Angew. Chem., Int. Ed. 2008, 47, 759. (c) Rueping, M.; Theissmann, T.; Raja, S.; Bats, J. W. Adv. Synth. Catal. 2008, 350, 1001. (d) Rueping, M.; Theissmann, T. Chem. Sci. 2010, 1, 473.

(22) For recent reviews on catalyst combined by metal and chiral phosphoric acids, see: (a) Shao, Z. H.; Zhang, H. B. Chem. Soc. Rev. 2009, 38, 2745. (b) Rueping, M.; Koenigs, R.; Atodiresei, I. Chem.Eur. J. 2010, 16, 9350. (c) Zhou, J. Chem. Asian J. 2010, 5, 422. (d) Zhong, C.; Shi, X. D. Eur. J. Org. Chem. 2010, 2999. 